\title{
Skeleton Ice Crystals of Non-Hexagonal Shape Grown in Free Fall*
}

\author{
By Akira Yamashita \\ Geophysical Institute, Tokyo University, Tokyo \\ (Manuscript received 13 January 1971, in revised form 1 May 1971)
}

\begin{abstract}
A large cloud chamber of about 15 meter high made possible to observe ice crystals grown in free fall. During the experiments carried out by using several seeding methods it was found that the seeding method to use a cold body produced not only usual ice crystals of hexagonal shape but also several kinds of very interesting skeleton ice crystals of non-hexagonal shape. As a cold body a metal rod chilled by liquid nitrogen or by dry ice was used. The temperature range at which those crystals were found were $-1.9 \sim-11.1^{\circ} \mathrm{C}$ and $<-20^{\circ} \mathrm{C}$. These ice crystals are thought started their growth at the special initial conditions of extraordinary high supersaturation. Their growth modes are mainly determined by air temperature as shown by the fact that those grown at high temperature $\left(-1.9 \sim-11.1^{\circ} \mathrm{C}\right)$ and those grown at low temperature $\left(<-20^{\circ} \mathrm{C}\right)$ were very different in appearance.

From a crystallographic point of view the formation of these skeleton ice crystals of nonhexagonal shape presents the three important facts as follows. One is that initial condition of ice crystal formation is possible to affect the later growth habit seriously, another is that an ice dendrite growing in the $\langle 11 \overline{2} l\rangle$ direction is possible to be understood as a growth along skeleton arm and the other is that the growth of both inside plane and pyramidal plane are possible. (The definitions of skeleton arm and inside plane are presented in section 3)
\end{abstract}

\section{Introduction}

Experimental studies on the growth of snow crystals have been made by many workers, for example Nakaya (1954), Kobayashi (1957) and Hallett et al (1958), and it is likely to be almost established that the temperature at which the growth takes place is the main factor governing the crystal habit. Although almost all of them made their experiments suspending ice crystals on rabbit hair or on fiber in comparatively small cloud chambers, aufm Kampe et al (1951) and Yamashita (1969) made experiments in cold rooms by dry ice seeding method and noticed the formation of trapezoid ice crystals. Especially Yamashita (1969) found the growth of not only trapezoids but also trigonal columns, trigonal pyramids and those having complex appearances.

The present series of investigation started by the thought that experiments to study natural snow crystals should be made in a large cloud chamber so that ice crystals grow in free fall. In

* Division of Meteorology, Contribution No. 199. this article not only several new types of ice crystals which had grown in a dense supercooled cloud are presented as a preliminary report, but also their growth model and crystallographic meaning are discussed.

\section{Apparatus and experimental procedure}

The large cloud chamber constructed in our laboratory is made of a stainless steel pipe of about 15 meter in height and $28 \mathrm{~cm}$ in diameter. As was shown in the previous paper (Takahashi and Yamashita, 1970), it has four observation windows, one cap for various operations at the top and one sampling door at the bottom which is put in a deep freeze. All of these are closed tight to keep cold air in the chamber as stable as possible. Temperature in the chamber is controlled automatically down to $-36^{\circ} \mathrm{C}$ and is able to be kept uniform from the level $50 \mathrm{~cm}$ below the top to the bottom without regard to the existence of a supercooled cloud. Fig. 1 shows the apparatus and five examples of vertical temperature distribution in the chamber without a supercooled cloud and two examples (III', III') with a super- 


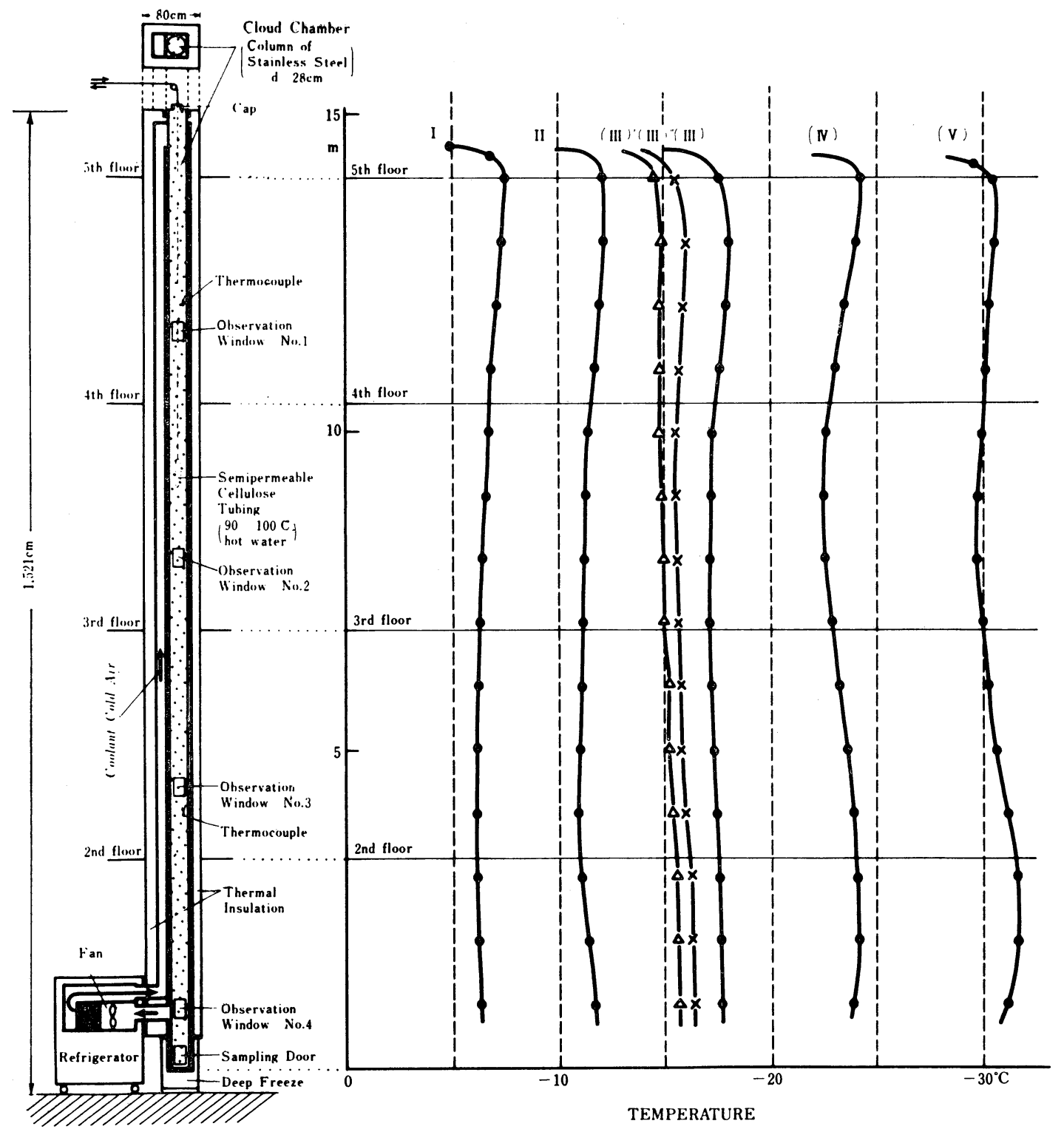

Fig. 1. Section of the apparatus and vertical temperature distridutions before the humidification ((I), (II), (III), (IV) and (V)). (III) ${ }^{\prime}$ and (III) ${ }^{\prime \prime}$ are the temperature distributions after two and seven minutes respectively from the humidification which was made at the temperature distribution (III).

cooled cloud. Horizontal temperature distribution was uniform although there was a slight periodic oscilations within $\pm 0.2^{\circ} \mathrm{C}$.

Experiments were performed in a following way. The cloud chamber was humidified by introducing a semipermeable cellulose bag which contained about $800 \mathrm{cc}$ of hot water (of about $70^{\circ} \mathrm{C}$ ). Within $60 \sim 90$ seconds the bag was introduced from the top, hung down to the bottom and removed from the top of the chamber. Temperature in the chamber became stable at about a few minutes after the humidification as shown in Fig. 1 (III) (III) ${ }^{\prime \prime}$. Supercooled cloud formed in the chamber was stable for more than ten minutes. As an example of the size distribution and the concentration of supercooled water droplets is shown in 


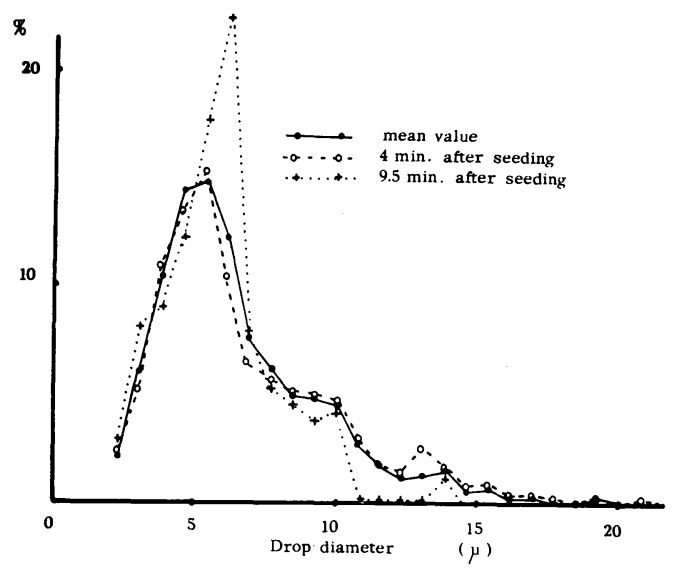

Fig. 2. An example of the size distribution of supercooled water droplets in the chamber. It was almost constant during the experiment from the top to the bottom of the chamber.

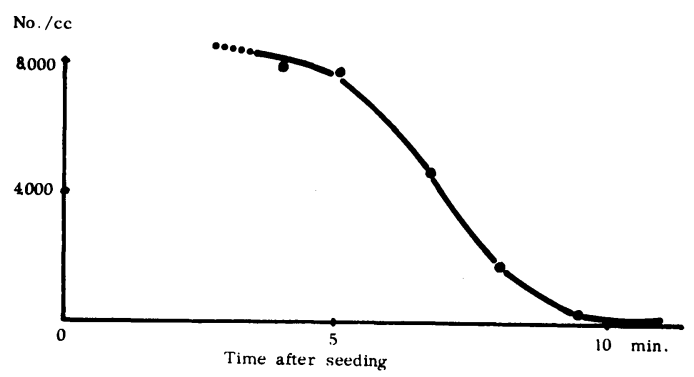

Fig. 3. An example of the concentration of water droplets in the chamber. The sampling of ice crystals was made between 3 and 10 minutes after seeding. Experiments in the present paper were conducted at almost the same condition.

Fig. 2 and Fig. 3 respectively, ice crystals shown in the present paper had grown in a dense supercooled cloud.

Among various methods of making ice crystals only the method to introduce a chilled metal rod in a supercooled cloud is employed in this study. The chilled part of the rod is about $10 \mathrm{~cm}$ in length and $2 \mathrm{~mm}$ in diameter and is introduced from the top of the chamber down to the level about $70 \mathrm{~cm}$ below the top, where the air has been cooled to the required temperature of each experiment. It is removed again from the top within $1 \sim 2$ second. Temperature of the chilled rod is thought to be a little higher than $-78.5^{\circ} \mathrm{C}$ when dry ice is used and a little higher than

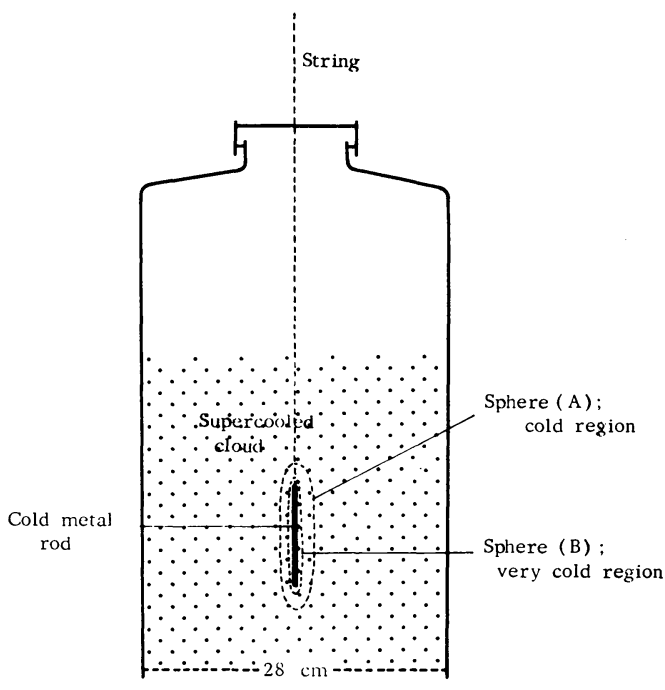

Fig. .4 The seeding method using a cold metal rod. The rod which is chilled by liquid nitrogen or by dry ice hung down about $80 \mathrm{~cm}$ from the top of the chamber for only about one second in a supercoolded cloud. The level is necessary to be cooled to the required temperature for the experiment.

Region (A): Cold region where water droplets are thought to freeze spontaneously.

Region (B): Very cold region where water droplets freeze spontaneously and many ice crystals are produced on ions or the likes.

$-195.8^{\circ} \mathrm{C}$ when liquid nitrogen is used. Though the number of them is not controlled in this series of experiments, numerous ice crystals formed by rapid cooling will be partly originated from frozen cloud droplets and partly originated directly on minute nuclei of ions or the like at abnormally high supersaturation (see Fig. 4). They grow falling about 14 meters in the chamber and can be sampled from about 3.5 minutes to about 15 minutes at the sampling door. They are sampled on the surface of highly viscous $(10,000$ c. s.) silicone oil stored in a glass dish and kept at the chamber's temperature. After the sampling ice crystals are covered by thin cover glasses as soon as possible. The oil is confirmed not to affect the growth of ice crystals.

The sampling is made in a following way. After the sampling door is opened, the dish is placed at the bottom of the chamber for $5 \sim 60$ 


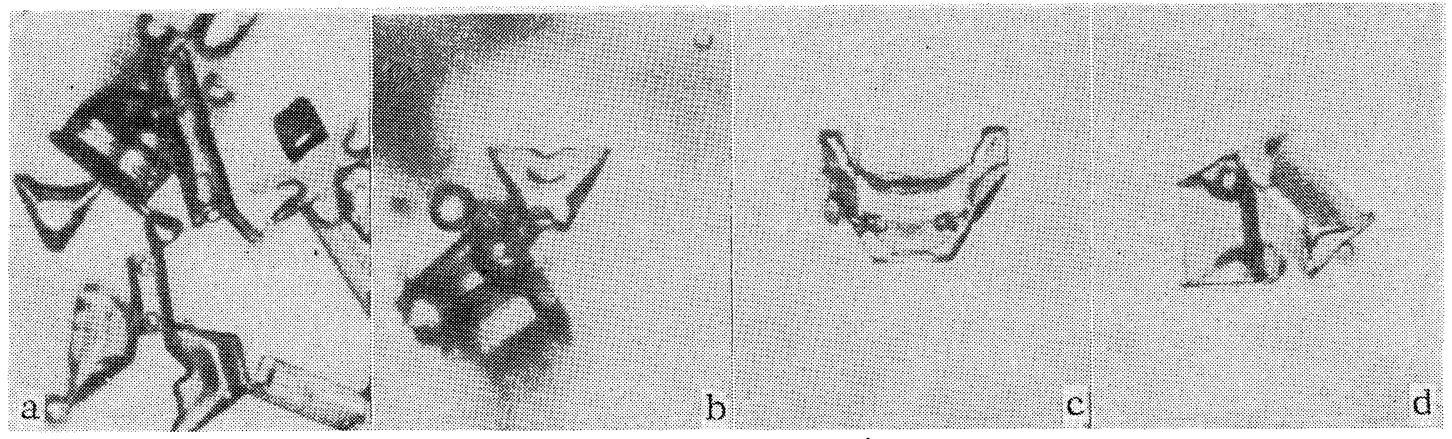

a; $-3.9^{\circ} \mathrm{C}, \mathrm{b}, \mathrm{c}, \mathrm{d} ;-3.5^{\circ} \mathrm{C}$, ( liq. nitrogen ) ( falling distance; $7 \mathrm{~m}$. )

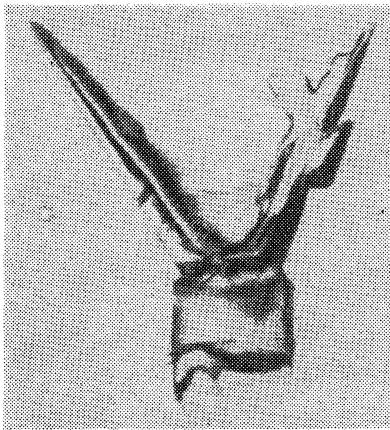

e $-\mathrm{h} ;-4.0^{\circ} \mathrm{C}, \quad($ dry ice $)$
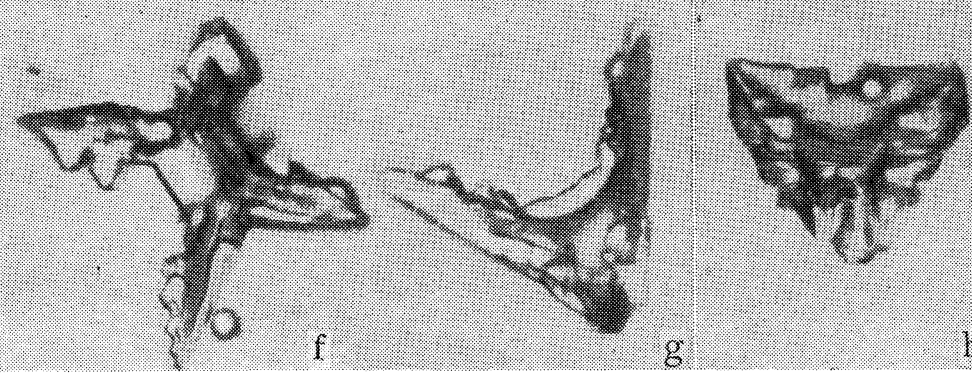

in

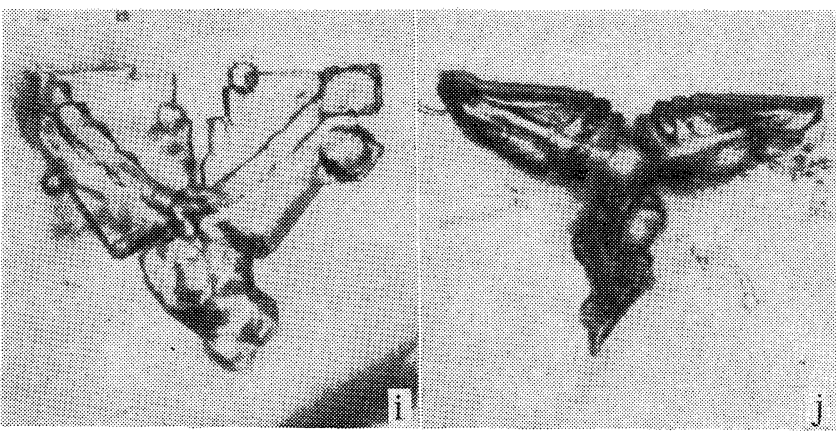

i $-1 ;-6.7^{\circ} \mathrm{C}, \quad($ liq. nitrogen $)$



$\mathrm{m}-0 ;-6.7^{\circ} \mathrm{C}, \quad\left(\right.$ liq. nitrogen ) p, q; $-4.0^{\circ} \mathrm{C}, \quad$ (dry ice )

Fig. 5. Skeleton ice crystals of non-hexagonal shape grown at $-3.5,-3.9,-4.0$ and $6.7^{\circ} \mathrm{C}(\times 233)$. 

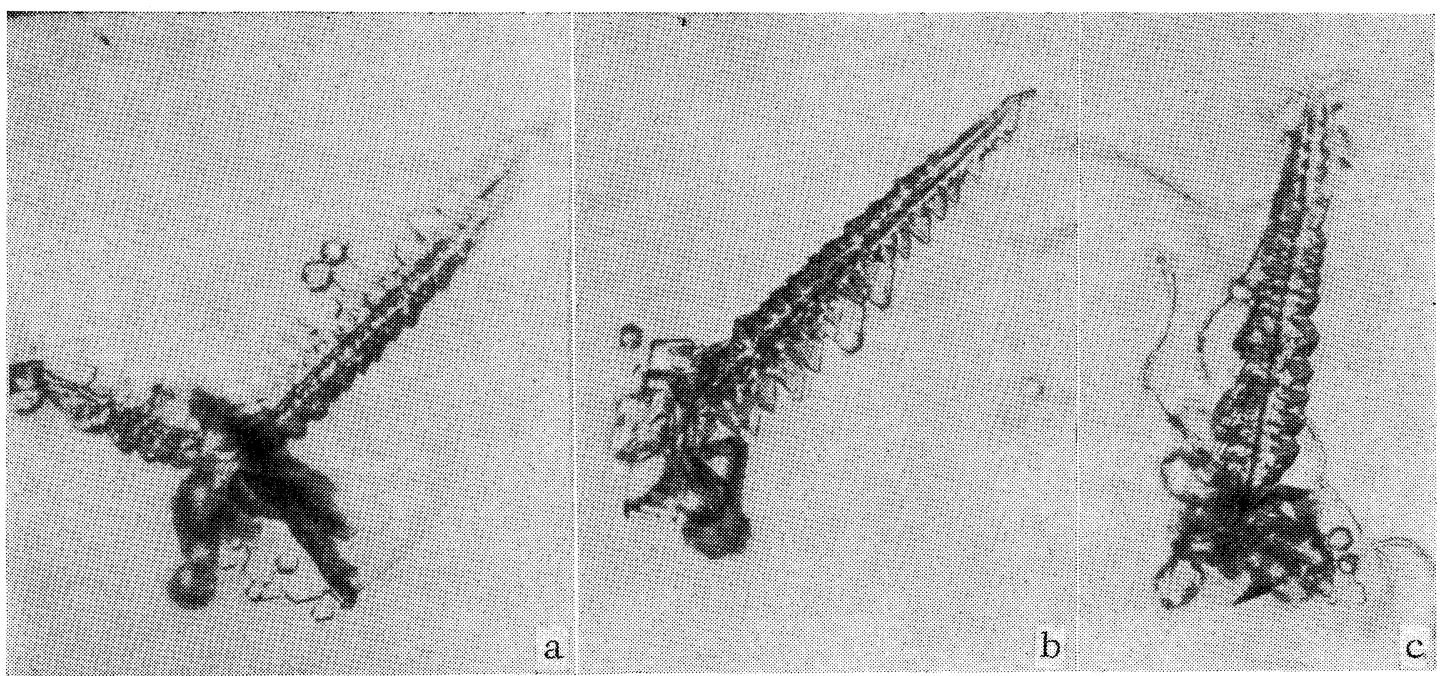

$\mathrm{a}, \mathrm{b} ;-26.1^{\circ} \mathrm{C}, \mathrm{c} ;-24.5^{\circ} \mathrm{C}, \quad$ ( liq. nitrogen )
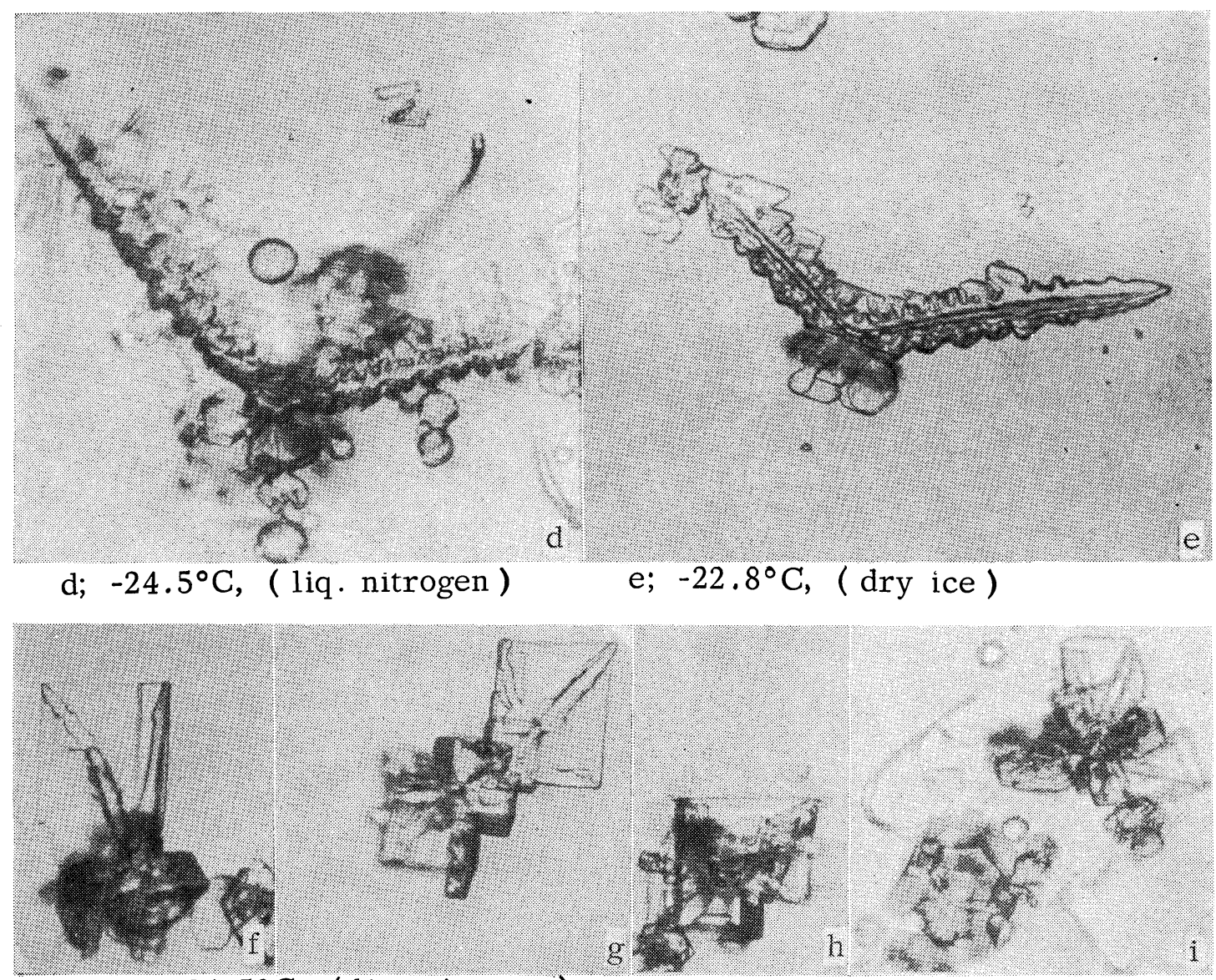

f - i; $-24.5^{\circ} \mathrm{C}$, ( liq. nitrogen)

Fig. 6. Skeleton ice crystals of non-hexagonal shape grown at $-22.8,-24.5$ and $-26.1^{\circ} \mathrm{C}(\times 233)$. 


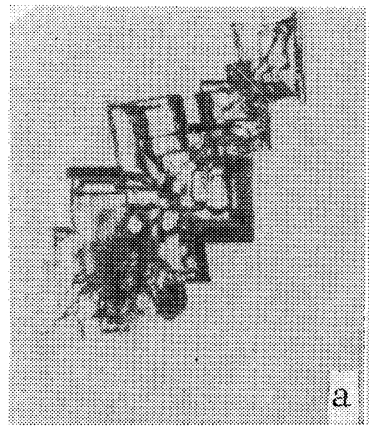

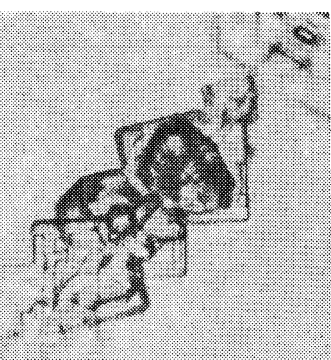

b

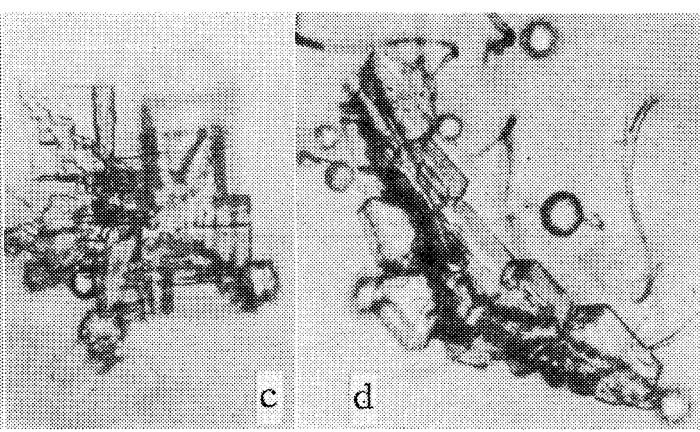

$\mathrm{a} ;-26.1^{\circ} \mathrm{C}, \quad \mathrm{b}, \mathrm{c}, \mathrm{d} ;-24.5^{\circ} \mathrm{C}, \quad$ ( liq. nitrogen )
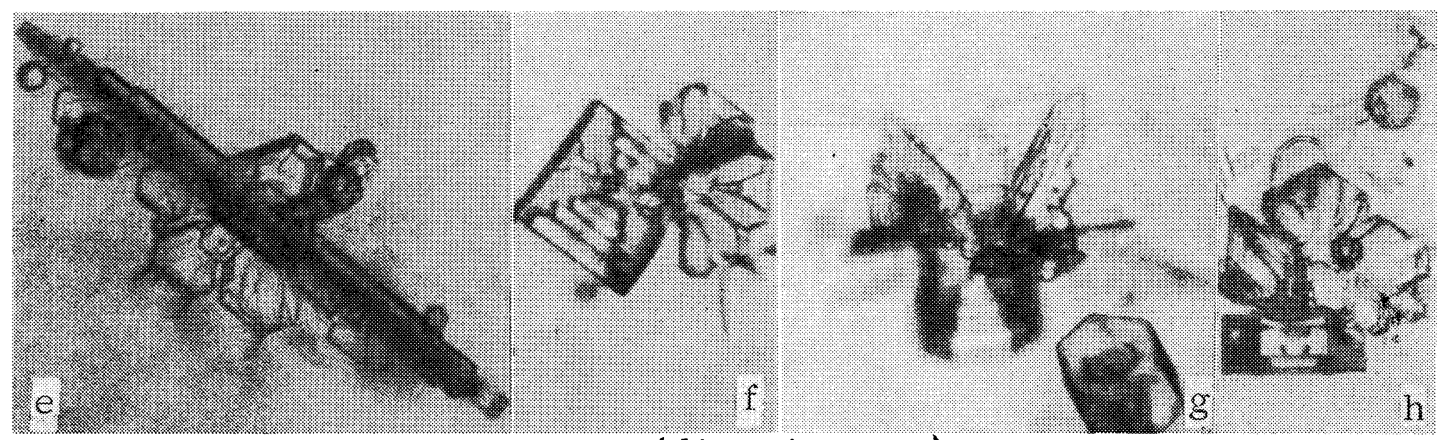

e, g; $-26.1^{\circ} \mathrm{C}, \mathrm{f}, \mathrm{h} ;-24.5^{\circ} \mathrm{C}, \quad$ ( liq. nitrogen )

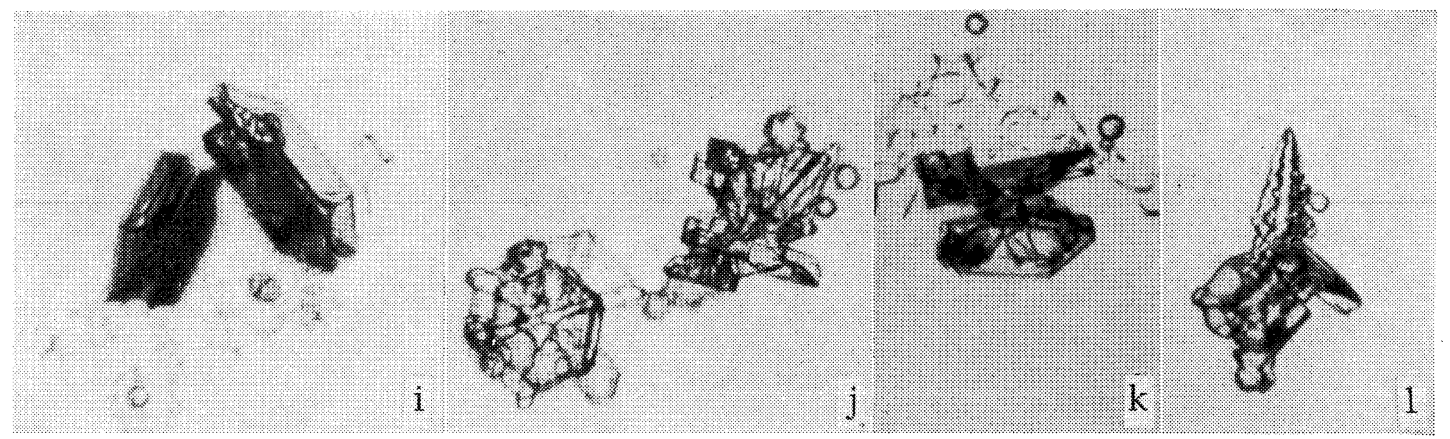

i $-1 ;-11.1^{\circ} \mathrm{C}, \quad$ ( liq. nitrogen )

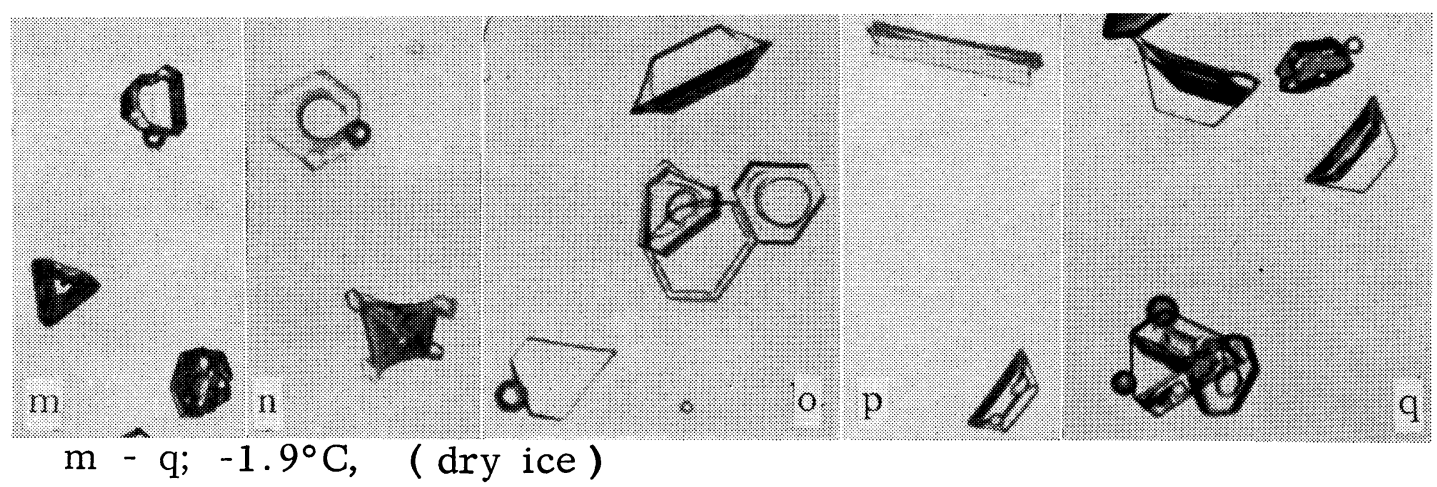

Fig. 7. Skeleton ice crystals of non-hexagonal shape grown at $-24.5,-26.1,-11.1$ and $-1.9^{\circ} \mathrm{C}(\mathrm{a} \sim \mathrm{h} \times 233, \mathrm{i} \sim \mathrm{q} \times 146)$. Usual hexagonal ice crystals are also shown in this figure. 
seconds. Then it is removed from the chamber and the sampling door is closed. The process to put cover glasses on ice crystals is made in the deep freeze.

Sampled ice crystals are carried to a cold room without changing their temperature to examine by an ordinary microscope or by a polarization microscope. Photomicrographs are taken as much as possible to examine them in detail. These operations should be made as rapidly as possible to observe ice crystals with no deformations.

Temperatures shown in this paper are the mean air temperatures in the cloud chamber.

\section{Growth of skeleton ice crystals of non-hexagonal shape}

(i) Uncommon ice crystals produced by an extremely cold body

At the preliminary experiments ice crystals were made at $-3.5^{\circ} \mathrm{C}$ and $-3.9^{\circ} \mathrm{C}$ by introducing an extremely cold metal rod (chilled by liquid nitrogen) at the observation window No. 2 for one or a half second and the four types of uncommon ice crystals found by Yamashita (1969) were obtained again (see Fig. $5 \mathrm{a} \sim$ d). These were grown during their 7 meters' fall and were a little larger than those found previously.

The main series of experiments were made for the purpose to make them grow as large as possible at various temperatures by the same seeding method as the preliminary one (except the seeding was made at the top of the chamber). When the air temperature in the chamber was $-4.0,-6.7$, $-22.8,-24.5$ and $-26.1^{\circ} \mathrm{C}$ (Figs. 5, 6 and 7), various types of uncommon ice crystals grown during their 14 meters' fall were as large as about $100 \sim 200 \mu$ and were large enough to know their growth habits. However, at about $-15^{\circ} \mathrm{C}$ there were no uncommon ice crystals and many little snow flakes were observed, at $-11.1^{\circ} \mathrm{C}$ a

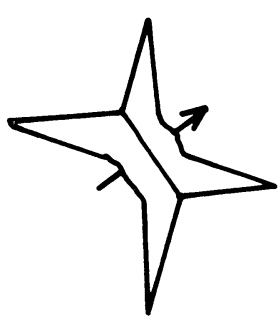

Fig.5 g

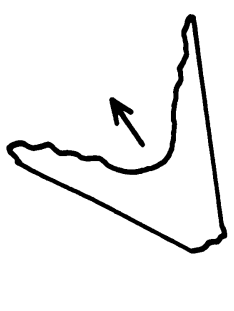

Fig. $5 \mathrm{f}$

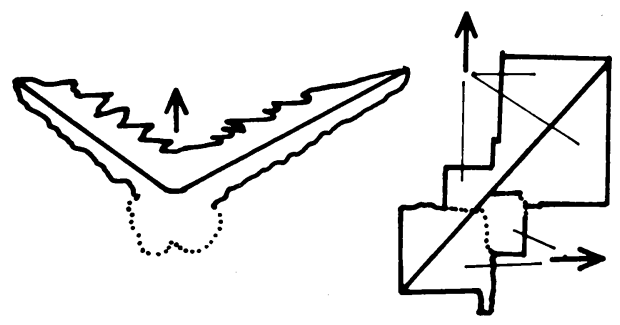

Fig. 6 a, d, e

Fig. $6 \mathrm{~g}$

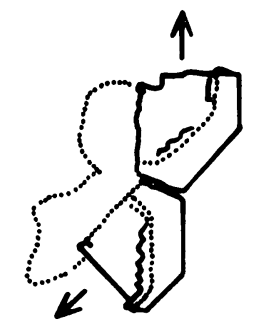

Fig. 5 o

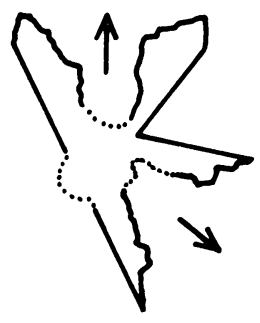

Fig. 5 q

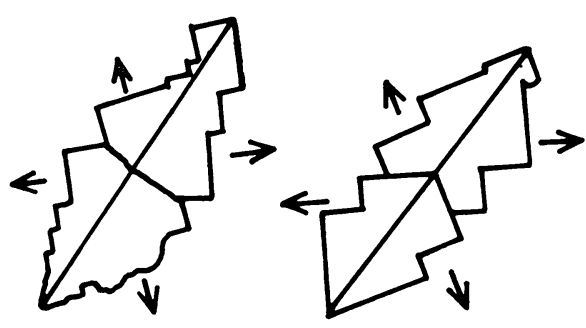

Fig.7 a

Fig. 7 b

The directions of c-axes are shown by arrows.

( the directions of $\mathrm{c}$-axes in the photographs are vertical );
Fig. 5 b, c, d(left), e, h, i, j, k, l, m. n.

Fig. 6 b, f, h.

Fig. $7 \mathrm{~g}$.

Fig. 8. c-axes of the ice crystals shown in Figs. 5,6 and 7. Only eight ice crystals are explained here because the other ice crystals have comparatively simple c-axes. Photographs in Figs. $5 \mathrm{~b}, \mathrm{c}, \mathrm{d}, \mathrm{e}, \mathrm{h}, \mathrm{i}, \mathrm{j}, \mathrm{k}, 1, \mathrm{~m}, \mathrm{n}, 6 \mathrm{~b}, \mathrm{f}, \mathrm{h}$, and $7 \mathrm{~g}$ are arranged as the c-axis looks up. 
small numbers of ice crystals which had partly the similar uncommon growth were observed (see Fig. $7 \mathrm{i} \sim 1$ ) and at $-1.9^{\circ} \mathrm{C}$ there were many uncommon crystals (see Fig. $7 \mathrm{~m} \sim \mathrm{q}$ ) but they were too small for us to examine their growth habits in detail.

From these experiments it has been found clearly that those looked like trapezoid grew to ice crystals like the letter $\mathrm{V}$. That is, the trapezoids in Fig. 5b and $\mathrm{c}$ are thought to grow to those shown in Fig. $5 \mathrm{~g}$ and $\mathrm{h}$ though these four crystals are different each other. As the similar way those looked like tetrahedron is also thought to grow to those shown in Fig. $5 \mathrm{~h}$ or $\mathrm{j}$.

These uncommon ice crystals were examined under a microscope and were analized by careful comparisons of their interesting shapes one another considering the directions of c-axes (see Fig. 8), which were determined by the observation using a polarization microscope. It became clear that most of these ice crystals are a kind of skeleton ice crystals.

(ii) What are the uncommon ice crystals?

To explain these uncommon ice crystals the definitions of several terms are explained in Fig.
9. Two kinds of planes in Fig. 9 (b), which are thought to be formed by edge growth of the crystal shown in Fig. 9 (a), will be called skeleton planes. They consist of 12 pyramidal planes and 6 inside planes as shown in the figure. As is shown in Fig. 10 an inside plane has two main

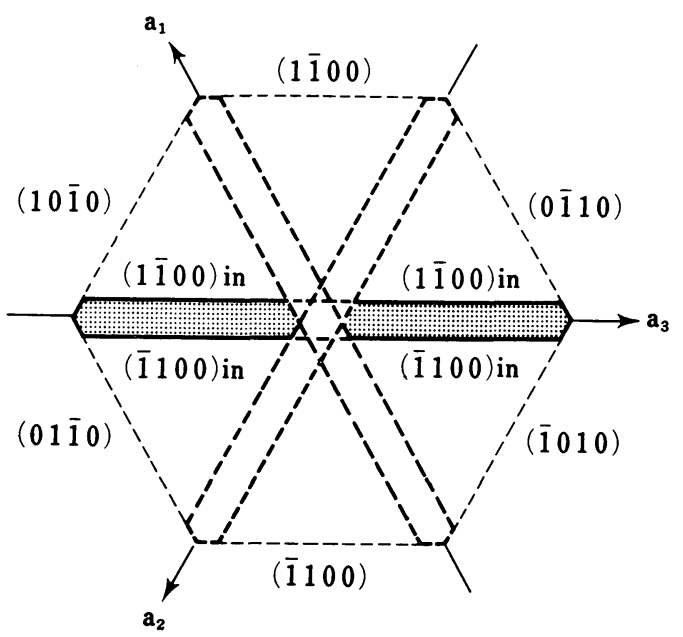

Fig. 10. A section to explain inside planes. The dotted area shows an inside plate crystal.

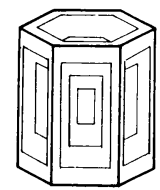

( a )

Skeleton Structure

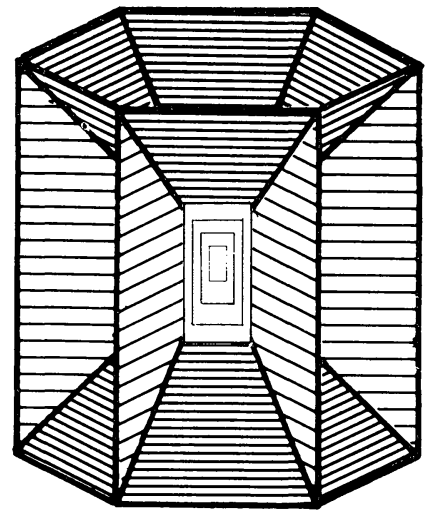

( b )

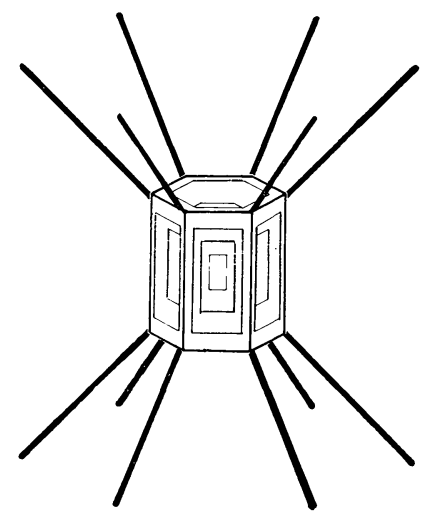

(c)

Skeleton arms

(corner growth from (a))

(edge growth from (a))

Fig. 9. The definition of the skeleton ice crystals. Skeleton planes are those which are left when skeleton structure develop for the extreme. Usually they are composed of 12 pyramidal planes (densely hatched) and 6 inside planes (coasely hatched). Skeleton arms are the twelve juctions of these planes and grow when skeleton planes grow little. 
faces, $(1 \overline{1} 00)_{i n}$ and $(\overline{1100})_{i n}$ and in some cases it will be called an inside plate. By this definition of inside plane, prism plane of usual hexagonal ice crystals will also be called outside plane. Because these two kind of planes are parallel and have the same crystallographic lattice, this classification of inside plane and outside plane are made only for the convenience of explaining skeleton ice crystals. A pyramidal plate may be defined as the same way. The 12 lines of contact of these planes will be called skeleton arms. Fig. 9 (c) shows the supposed ice crystal which may be formed by corner growth of the crystal shown in Fig. 9 (a). It is composed mainly of 12 skeleton arms growing towards $\langle 11 \overline{2} l\rangle$. In case of a solid hexagonal column or that having little skeleton structure, the lines between the center and the 12 corners of the crystal will be called skeleton arm, although it can not be defined strictly. The 12 directions shown by $\langle 1 \overline{12} l\rangle$ are not always constant but can vary by the change of growing conditions.

There were three fundamental types of skeleton ice crystals of non-hexagonal shape. They are shown in Fig. 11. In this figure $\left(a^{\prime}\right)$ and $\left(b^{\prime}\right)$ explain what parts of hexagonal columnar ice crystals (a) and (b) correspond to respectively. c-axis of the crystal (c) is shown in $\left(c^{\prime}\right)$. One of the three was that composed mainly of dendrites grown along skeleton arms (Fig. 5c, f, g, j, q and Fig. 11a), another was that of which inside planes developed and skeleton arms were also found (Fig. 5h, i, k, o and Fig. 11b) and the other was that of trigonal columns (Fig. 5d, 1 and Fig. 11c). Fig. $5 \mathrm{~m}$ and $\mathrm{n}$ are shown because they clearly explain the relation between the arm growth (hereafer dendritic growth along a skeleton arm will be called only "arm growth") and the growth of usual columnar ice crystals.

Concerning the number of skeleton arms of skeleton ice crystals only those having one, two, three and four arms were found at the four

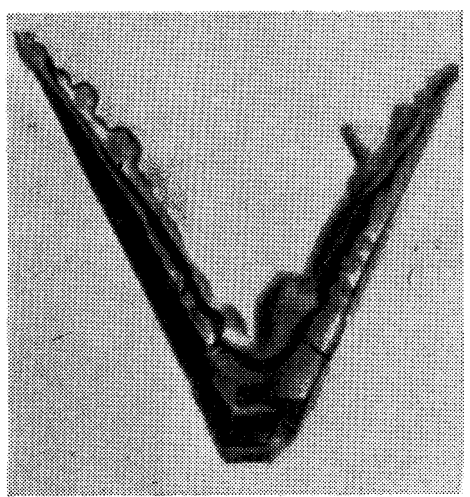

(a)

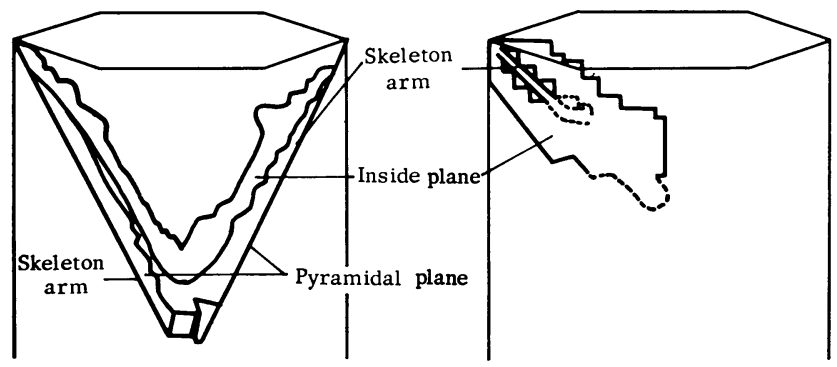

( a')

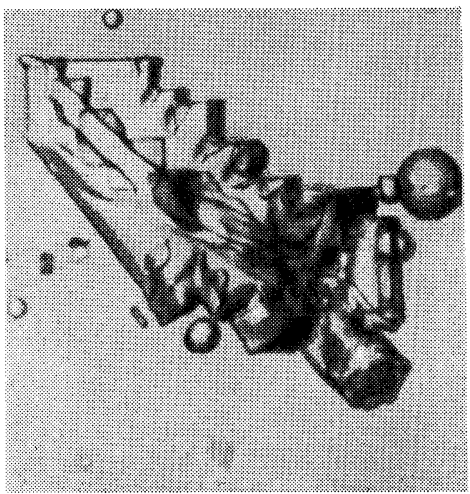

(b)

( b' )

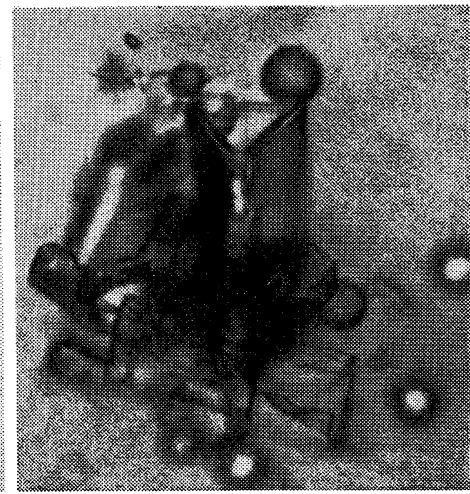

(c)

Fig. 11. Three types of skeleton ice crystals on non-hexagonal shape $(\times 277)$. $\left(a^{\prime}\right),\left(b^{\prime}\right)$ and $\left(c^{\prime}\right)$ are for the explanation of the corresponding three ice crystals (a), (b) and (c) respectively. (a) is one of the most representative arm growth having two arms. (b) is mainly composed of an inside plane and steps are found at an edge and along the skeleton arm. (c) is a trigonal column. 


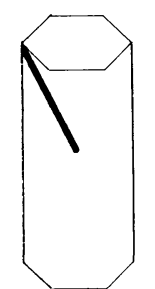

(a)

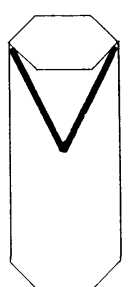

(b)

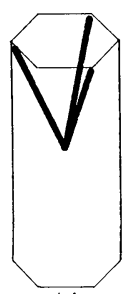

(c)

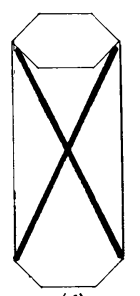

(d)

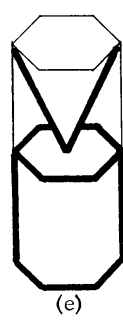

e)
Fig. 12. Five typical ice crystals composed of skeleton arms. The last one is a complex type.

different temperatures $(-3.5,-3.9,-4.0,-6.7$ $\left.{ }^{\circ} \mathrm{C}\right)$. They are shown in Fig. 5 and explained in Fig. 12, although in case of multi-arm crystals there could be many possible combinations of twelve arms (see Fig. 9). Among them there were also twin or poly ice crystals and they made the detailed analysis of these crystals difficult.

In case of inside plate (Fig. 5i, k and Fig. 11b) the step growth which corresponded to the step growth of usual skeleton structure was found (sometimes the similar steps could be found at their arms) and the plate sometimes had a little scroll structure at its edge (see Fig. 5k, o and Fig. 6f, g).

Trigonal columns had hollow structure. There were no knowing whether the crystal is surrounded by one prism (outside) plane and two inside planes or it is surrounded by three prism (outside) planes. The ice crystal shown in Fig. 51 suggests that the former explanation will be correct. However, that shown in Fig. 5d might support the latter explanation.*

At almost all experiments there were not only skeleton ice crystals of the simple forms explained above but also very complex skeleton ice crystals. Complex of more than two skeleton ice crystals of non-hexagonal shape (see Fig. $5 \mathrm{o}, \mathrm{q}$ ) and the complex of skeleton ice crystals and usual hexagonal ice crystals (see Figs. 5e, p, 6b), were found. Among these complex crystals many poly-crystals (twin are the most abundant) were observed by a polarization microscope. During the observation it was found that considerable amount of irregular ice crystals, which were too complicated and small to be disclosed their growth habit, might possibly belong to these groups of

* Recent experiments to make ice crystals by adiabatic expansion disclosed the nature of trigonal ice crystals (Yamashita, 1971). skeleton ice crystals.

(iii) Those grown at higher than $-10^{\circ} \mathrm{C}$ (se? Fig. 5)

Table 1 shows the production rates of various skeleton ice crystals of non-hexagonal shape at different temperatures. Among the experiments made at higher than $-10^{\circ} \mathrm{C}$ those at $-1.9,-4.0$ and $6.7^{\circ} \mathrm{C}$ produced many skeleton ice crystals of non-hexagonal spape, though at $-1.9^{\circ} \mathrm{C}$ they were too small to be analized in detail. They were $60 \sim 70 \%$ of all ice crystals at -4.0 and $-6.7^{\circ} \mathrm{C}$ and, except complex skeleton ice crystals, two-arm crystals were the most in number. Trigonal columns, one-arm crystals, four-arm crystals and three-arm crystals followed in number. Growth of inside plane was limited to one-arm crystals, two-arm crystals and some complex skeleton crystals. Distinct steps at the edges and at the arms (Fig, 11b, 5i, k, o) of inside plates were clearly found at this temperature range. Scroll growth (Fig. 5k, o) was also observed sometimes.

(iv) Those grown at $-20 \sim 30^{\circ} \mathrm{C}$ (see Figs. 6 and $7 a \sim h$ )

Production rates are also summarized in Table 1. One-arm and two-arm skeleton ice crystals were also observed at $-22.8,-24.5$ and -26.1 ${ }^{\circ} \mathrm{C}$, although their dendritic appearance were quite different from those formed at higher temperature by their representative dendritic growth (Fig. 6a e). Trigonal columns, three-arm and four-arm crystals were not found at this temperature range. Growth of inside plane was observed and their appearance was almost the same as those formed at the higher temperature except that less distinct steps and more scroll growth were found at their edges (Fig. $6 \mathrm{f} \sim \mathrm{i}$ ).

At this temperature range there were more possibility of forming poly-crystals than at the higher temperature and, therefore, many complex skeleton ice crystals were observed.

What is interesting is that many interesting complicated ice crystals were observed at this temperature range. Among them twin (or poly) crystals as shown in Fig. 7a and b are thought to be intimately related to arm growth of skeleton ice crystals. Among their four c-axes explained in Fig. 8a and b there were two parallel axes. Fig. $7 f$, $g$ and $h$ show an example of arm growth from columnar ice crystals.

What was important about the growth of 


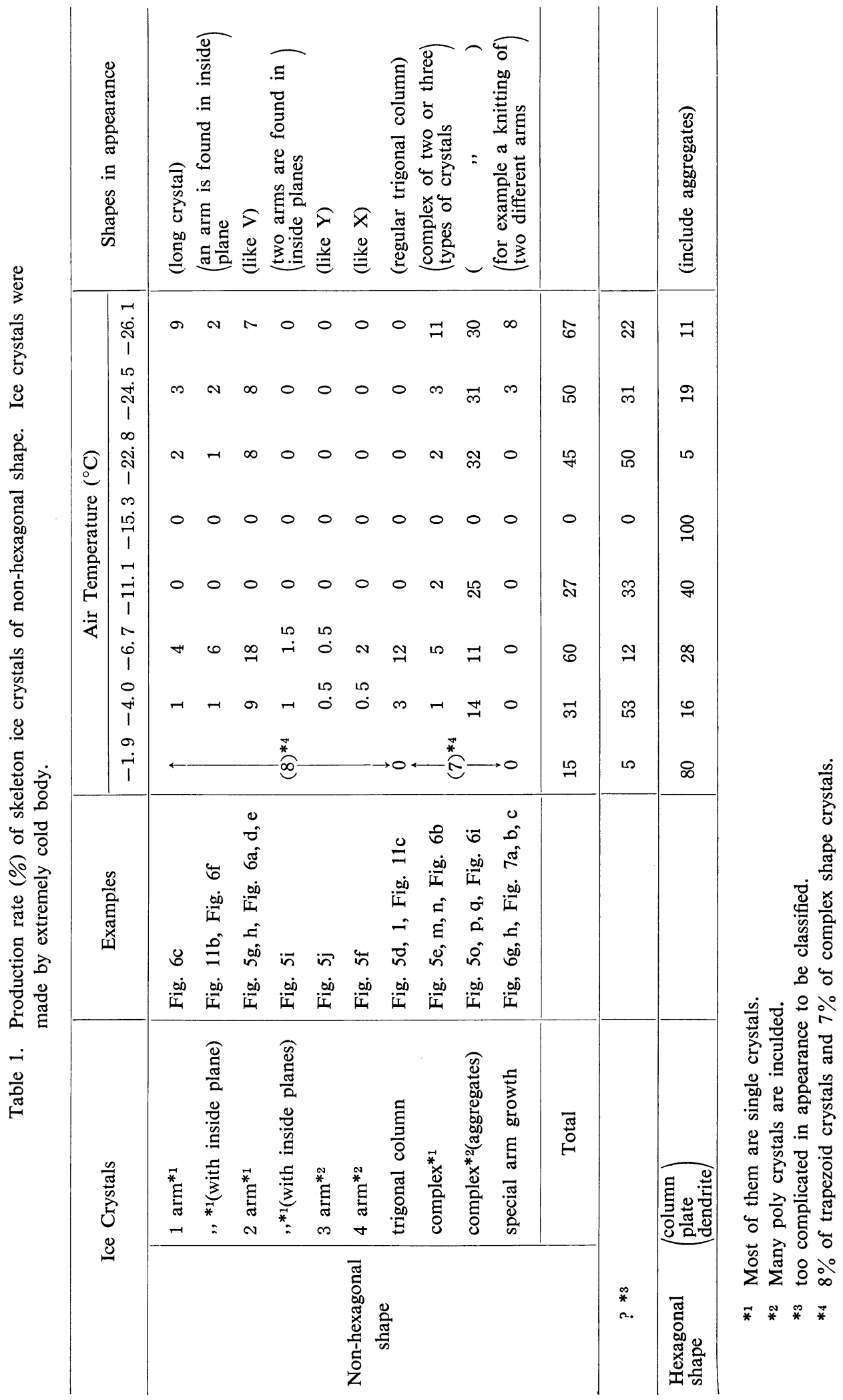




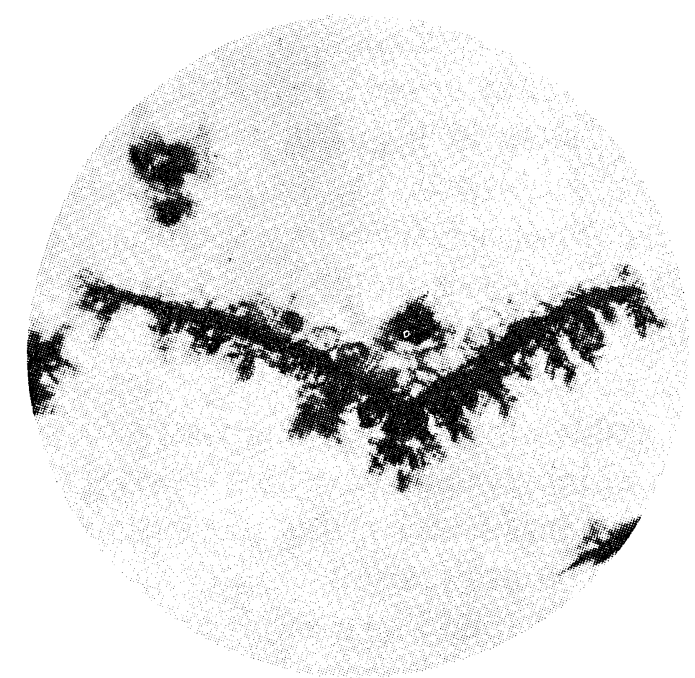

Fig. 13. A natural two-arm snow crystal $(\times 6.7)$ (Nakaya, 1954).

skeleton arms and skeleton planes at this temperature range was that by natural ice nuclei in Tokyo air or even by the seeding methods using clay minerals or silver iodide suspension droplets a little amount of one-arm skeleton ice crystals, few two-arm skeleton ice crystals and the growth of inside plane were found although three or four arm crystals were not found as yet in our experiments. Among natural snow crystals arranged by Nakaya (1954) there are not only several one-arm snow crystals but also one two-arm snow crystal (see Fig. 13) which must be an equal type of the crystal as shown in Fig. 6a, c and d. Some of the peculiar snow crystals observed by Kikuchi (1970) in Antarctica are thought to be the same kind of ice crystals as shown in the present paper.

(v) Growth habit of two arm skeleton crystal ( $V$-shaped crystal)

Two-arm skeleton ice crystals (V-shaped crystals) were the most common skeleton ice crystals produced by the seeding method in the present paper. The angle between two arms was found to vary by temperature at which they grew. For example, at $-4.0,-6.7,-22.8,-24.5$ and $26.1^{\circ} \mathrm{C}$ its mean value was $59^{\circ}, 67^{\circ}, 128^{\circ}, 118^{\circ}$ and $108^{\circ}$ respectively. At $<-20^{\circ} \mathrm{C}$ it decreased clearly as the air temperature became low.

\section{Discussions}

\section{(a) Analysis of uncommon ice crystals}

Before those ice crystals were classified as skele- ton ice crystals of non-hexagonal shape many discussions were necessary by using all of the experimental results. An skeleton ice crystal which has no hexagonal symmetry was not easily determined its crystallographic planes by observing only one crystal. However, by observing many of those crystals under an ordinary microscope and an polarization microscope following key points to solve their crystal structures were found. The V-shaped ice crystals (Figs. 5g, h, 6a, d, e, 11a) were thick enough to be observed under a polarization microscope. They grew not in basal plane but had their c-axis at the center of two growth directions. The axes were easily determined by the help of $530 \mathrm{~m} \mu$ sensitive color plate mounted on a polarization microscope. Dendritic growth of V-shaped crystals (Fig. 6a, d, c) at the low temperature range were different from usual ice dendrites in appearance by their regular steps, by their variable growing directions $\langle 11 \overline{2} l\rangle$ and by the parallel growth direction of branches in inside plane. Tetragonal plates (Figs. 5i, 6f, g, 11b) had always right angles at their corners. Every one of them had always a diagonal arm and some of them had clear steps of right angles. There were many hexagonal columns and trigonal columns and a few intermediate crystals of them (Trigonal nature of ice crystals will be discussed in the other paper (Yamashita, 1971)). Considering these facts derived mainly from morphological study, the concepts of skeleton ice crystal of non-hexagonal shape and arm growth as shown in the previous section were derived. After these concepts were introduced there were no simple single crystals which could not be found their crystallographic classifications. Still more at low temperature between $-20 \sim-30^{\circ} \mathrm{C}$ dendritic growth (or corner growth) along skeleton arms was found on usual columnar skeleton ice crystals.

In the model explained in Figs. 9 and 10 skeleton arms can vary their directions of $\langle 11 \overline{2} l\rangle$ during growing in inside planes (because $l$ is variable) and, therefore, pyramidal planes are not always flat planes. However, in this series of experiment almost all growth directions of skeleton arms were straight. This will be understood natural if we consider the almost constant temperature distribution in the chamber. 
(b) Stepped growth model of skeleton ice crystals of non-hexagonal shape

Ice crystals which grow in supercooled distilled water or in supercooled aqueous solutions were studied by Macklin et al (1965), Lindenmeyer et al (1966) and Pruppacher (1967). It has been found that ice dendrites do not necessarily propagate in a low-index crystallographic direction but at between -2.9 and $-6.5^{\circ} \mathrm{C}$ (Macklin et al, 1965) form a bi-pyramidal crystal like twelve pyramidal planes in Fig. $9 \mathrm{~b}$ growing primarily along twelve symmetric directions $\langle 11 \bar{z} l\rangle$. Comparing their experimental result with the skeleton ice srystals in the present paper, there is one important similarity that the primary growth of them is towards the direction $\langle 11 \bar{\angle} l\rangle$. If it is admitted to consider the bi-pyramidal crystals in supercooled water as a skeleton ice crystal of hexagonal shape having twelve pyramidal planes (Fig. 9 (b)), the proposed arm growth mechanism in the present paper will also be reasonably adapted to the bi-pyramidal ice crystal in a supercooled water. Further, a stepped growth mechanism proposed by Mason et al (1963) and adapted by Macklin et al (1965) to explain the growth of pyramidal planes in supercooled water and aqueous solution will also be possible to be extended to the growth of skeleton ice crystals of non-hexagonal shape in vapor. Fig. 14 (a) shows a model of two arm skeleton ice crystal (V-shaped crystal). At the skeleton arm of the left side of the figure step growth in two pyramidal planes $(10 \overline{1} l)$ and $(01 \bar{l} l)$ and the growth in the inside plane $(1 \overline{100})_{\text {in }}$ cross each other, though the growth in one of the two pyramidal planes was hardly confirmed by usual observation. The modified model shown in Fig. 14 (b), having a little pyramidal plane and large inside plane penetrating the skeleton arm, is presented to explain the inside plate (Fig. 11b) and if this model crystal is looked horizontally with basal plane tetragonal shaped steps at the skeleton arm will be found. Both in Fig. 14 (a) and Fig. 14 (b) the step growth model in inside plate is limited to one corner as shown in the figure and not adapted to the thickening growth of the plate because the growth was not obvious.

This model will need much more experimental supports in future, however, there are several important supports which we can find in this series of experiments. What is the most important is skeleton ice crystals of non-hexagonal shape having one or two arms grown at lower

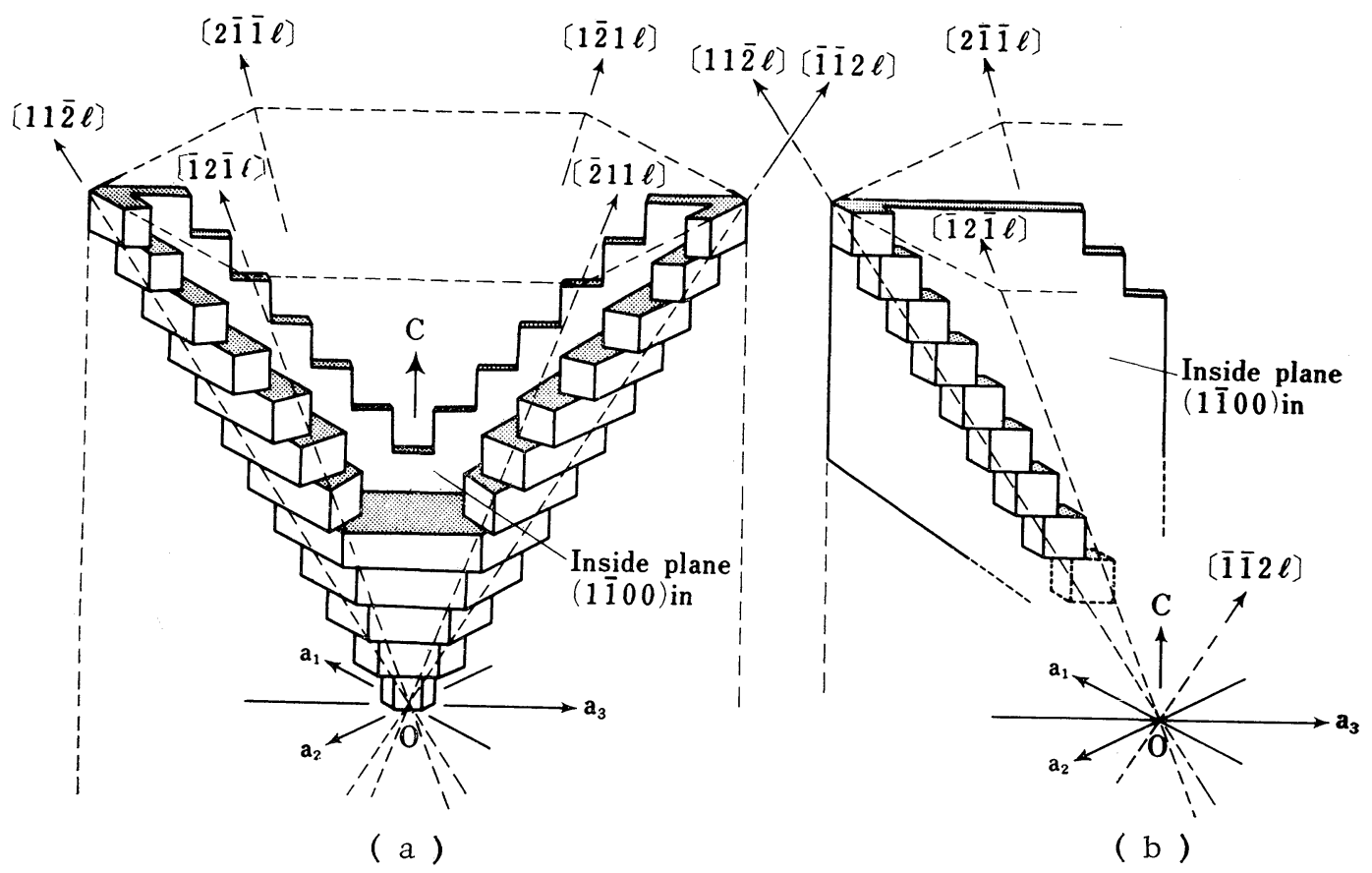

Fig. 14. (a) A stepped growth model of a two- arm (V-shaped) ice crystals. (b) A stepped growth model of an inside plate. The dotted areas show the basal plane. 
than $-20^{\circ} \mathrm{C}$ (Fig. 6a $\sim$ e). Clear visible steplike structures are found along the skeleton arm and especially step growth of inside plane shows interesting figures having parallel edges. Clear right-angled steps in one corner of inside plate (Figs. 5i, k, 11b) correspond to the usual skeleton growth in a basal plane of hexagonal ice crystals. The other corner which lies in the plane between $[11 \overline{2} l]$ and $[11 \overline{2} \bar{l} \bar{l}$ directions has no visible steps and has the shape shown in Fig. 14 (b). Morphologically this can be thought natural if it is admitted to employ the skeleton ice crystals of hexagonal shape, in which no steps can be found at the corner, to understand the crystal. Clear right-angled steps along the skeleton arm (Fig. $11 \mathrm{~b}$, Fig. 5i, k, o) will also support the model shown in Fig. 14 (b) because the visible steps clearly show the growth of pyramidal planes along the skeleton arm. The problem whether the inside plate thickens by stepped growth mechanism or not is still questionable because no experimental result which suggest the growth is obtained yet.

The mechanism of skeleton arm growth can be understood in contrast to the stepped growth mechanism as follows. Arm growth is a kind of corner growth and the corner growth is enhanced specially because the growth of two pyramidal planes (for example $(10 \overline{1} l)$ and $(01 \overline{1} l)$ ) and two inside planes (although strictly the same two planes, $(1 \overline{100})_{i n}$, bounded by the arm) which cross each other are possible along the arm.

About the following two results which are interesting from the crystallographic point of view, further experimental works are expected to make discussions the more reliable. One is the scroll structure which is frequently observed at the edge of inside plate. For example, the crystal shown in Fig. 5k has a little scroll structure at its steps and the crystals in Fig. 6f, g, $i$ also have scrolls at the same edges. This scroll structure is interesting because it may have a intimate relation with cuplike ice crystals which consists of thin hexagonal walls. The other is the trigonal columns which are observed at $-3.5,-3.9,-4.0$ and $-6.7^{\circ} \mathrm{C}$. As there were a few intermediate ice crystals of hexagonal and trigonal column this trigonal crystal suggest the existence of trigonal ice crystal at least at this temperature range.

\section{(c) Effect of the initial condition}

The fact that skeleton ice crystals of non-hex- agonal shape are abundantly formed only by the seeding method using a cold metal chilled by liquid nitrogen or by dry ice presents an interesting factor which restricts the growth of ice crystals. That is, the initial condition of this seeding method profoundly effects the later growth at least at about $-1.9 \sim-11.1^{\circ} \mathrm{C}$ and at about $-20 \sim-30^{\circ} \mathrm{C}$. The results about the effect of initial conditions will be discussed elesewhere collectively.

About the arm growth it will be natural to consider that once the growth begin it continues as far as the growing condition changes little because it is a kind of corner growth.

The experimental two results that no skeleton ice crystals of non-hexagonal shape were found at about $-15^{\circ} \mathrm{C}$ and, on the other hand, at $-20 \sim-30^{\circ} \mathrm{C}$ they were produced a little by any seeding methods may be important to know the effect of initial conditions clearly.

\section{(d) Complicated skeleton ice crystals}

As is summarized in Table 1 there were many ordinary hexagonal crystals and many twin or poly-crystals. The latter had generally complicated appearance and were thought to be probably the mixtures of ordinary hexagonal ice crystals and skeleton ice crystals shown in the present paper.

Among complicated skeleton ice crystals there were many crystals which resembled morphologically with so-called side plane ice crystals. This problem will also be important to study ice crystals grown at lower than about $-20^{\circ} \mathrm{C}$.

\section{(e) Experimental technique}

As for the experimental technique as a whole, in spite of using the large cloud chamber there were several merits compared with those small cloud chamber which have been used in our laboratory. It was possible not only to control the temperature in the chamber almost at constant for sufficiently long time but also to keep with a little turbulent motion supercooled cloud droplets for about $10 \sim 20$ minutes at the manner shown in Figs. 2 and 3 . In spite of a little supply of glycerin on the side wall frost grew only slightly and thickened gradually during the experiments which were repeated from five to fifteen times a day. However, it was proved by background tests that the frost do not produce confusing ice particles which fell to the bottom of the chamber during the experiment. 
The cold metal rod, which was introduced for a moment after wiped with gauze at the top of the chamber to make ice crystals, was proved by careful observation not to let fall frost formed on the metal.

The sampling of ice crystals at the sampling door of the cloud chamber were made as fast as possible. However, sometimes when it was made in a particularly dense supercooled cloud ice crystals fallen on a cover glass had grown as window hoar ice crystals. These window hoar crystals were very interesting because of their growth along skeleton arms. However, they can be easily distinguished from ice crystals grown during falling in the cloud chamber because they were very large and grew on a cover glass.

\section{Concluding remarks}

In order to make quantitative analysis of the skeleton ice crystals of non-hexagonal shape, experimental conditions should be extended and controlled in more detail. Among them following three are very important because the air temperature can be controlled almost sufficiently down to $-36^{\circ} \mathrm{C}$. One is to change the temperature of the cold metal. This is not only important to know the highest temperature for producing skeleton ice crystals of nor-hexagonal shape but also indispensable to get the production rates of various crystals. Another is to control the abundance of supercooled water droplets and especially to get the stable condition with a little number of supercooled water droplets* will be very important. Because the effective supersaturation over ice for a falling ice crystal, which vary by the abundance of supercooled water droplets, is expected to play an important role on its corner growth, this will be essential to know the effect of initial conditions strictly as well as to know the effect of humidity on its crystal habit. The

* The recent experiment revealed that even at the low effective supersaturation over ice, that is, at the existence of supercooled water droplets of only $1 \sim 10 / \mathrm{cc}$, many uncommon ice crystals were formed by the same experimental method as employed in the present work. They included trapezoids, trigonal pyramids and complicated ice crystals, which must grow to be skeleton ice crystals. However, for our regret it was difficult to make them larger to analyze them in detail because even the large cloud chamber of about 14 meter was insufficient in height. other is to control skilfully the number of ice crystals which grow in the chamber to the appropriate number.

If these ice crystals are proved to be formed in natural clouds or in fogs by dry ice seeding technique, they can be a tracer especially at the higher temperature range of about $0 \sim-10^{\circ} \mathrm{C}$, although there is no knowing the reason why V-shaped ice crystals or other skeleton ice crystals have never been found at the dry ice seeding experiments in the fields.

Moreover, at the lower temperature range (lower than about $-20^{\circ} \mathrm{C}$ ) experiments more in detail not only by the seeding method using a cold body but also by other seeding methods will be expected to increase the crystallographic knowledges of so-called side plane ice crystals and other complicated ice crystals which grow at this temperature range.

In any way as the experimental results in the present paper are qualitative and limitted, further experiments are expected to make the crystallographic nature of ice crystals clear.

\section{Summary}

The large and improved cloud chamber, which is able to keep supercooled clouds stable at almost constant temperature for more than 15 minutes, made the experiments of the growth of ice crystals from the vapor very promising not only from a cloud physical point of view but also from a crystallographic point of view. In the present paper only skeleton ice crystals of non-hexagonal shape produced by the seeding method using a cold metal (chilled by dry ice or liquid nitrogen) are shown and discussed from a crystallographic interest as a preliminary report. The following results obtained in this series of experiment are those obtained in a dense supercooled cloud as shown in Figs. 2 and 3.

1) By the special seeding method using extremely cold body several kinds of skeleton ice crystals of non-hexagonal shape were formed at about $-1.9 \sim-11.1^{\circ} \mathrm{C}$ and at about $-20 \sim-30$ ${ }^{\circ} \mathrm{C}$.

2) Their growth habits at the higher temperature range were quite different from those at the lower temperature range although they were undoubtedly the same kind of skeleton ice crystals. What is interesting is that at the lower temperature range a little number of those skeleton ice 
crystals of non-hexagonal shape have been observed in natural snow crystals.

3) The fundamental growth modes of these ice crystals are characterized by arm growth, a kind of corner growth, along skeleton arm and growth of inside plane. The former growth was usually dendritic.

4) Their growth can be understood by the modified stepped growth mechanism, and if the mechanism is possible to be applied to usual hexagonal ice crystals it will present important knowledges about the growth of ice crystals.

5) The formation of these uncommon ice crystals suggests that the effect of initial conditions on the growth of ice crystals is serious. This problem will become important to know natural snow crystals which grow in long falling path of different conditions.

\section{Acknowledgements}

The author express his thanks to Dr. A. Ono of Meteorological Research Institute for his valuable suggestions and discussions and to Prof. K. Gambo and Prof. M. Yanai of Tokyo University for their encouragements throughout the course of this study. $\mathrm{He}$ is also extremely indebted to Mr. C. Takahashi who helped the experiments using the large cloud chamber and made valuable discussions with the author.

Thanks are extended to Prof. Y. Takano of the Cultural Course of Tokyo University for his valuable suggestions about the crystallographic representations.

\section{References}

aufm Kampe, H. J., H. K. Weickmann and J. J. Kelly, 1951: The influence of temperature on the shape of ice crystals growing at water saturation. $J$. Meteor., 8, 168-174.

Fukuta, N., 1969: Experimental studies on the growth of small ice crystals. J. Atmos. Sci., 26, 522-531.

Hallett, J. and B. J. Mason, 1958: The influence of temperature and supersaturation on the habit of ice crystals grown from the vapour. Quart. $J$. Roy. Meteor. Soc., 84, 440-453.

Kikuchi, K., 1970: Peculiar shapes of solid precipitation observed at Syowa Station, Antarctica. $J$. Meteor. Soc. Japan, 48, 243-249.

Kobayashi, T., 1957: Experimental researches on the snow crystal habit and growth by means of a diffusion cloud chamber. J. Meteor. Soc. Japan, 75th Anniv. Vol. 38-47.

Lindenmeyer, C. S. and B. Chalmers, 1966: Morphology of ice dendrites. J. chem. Phys., 45, 2804-2806.

Macklin, W. C. and B. F. Ryan, 1965: The structure of ice grown in bulk supercooled water. J. Atmos. Sci., 22, 452-459.

Mason, B. J., G. W. Bryant and A. P. Van den Heuval, 1963: The growth habits and surface structure of ice crystals. Phil. Mag., 8, 502-526.

Nakaya, U., 1954: Snow Crystals. Harvard Univ. Press. 63-65.

Pruppacher, H. R., 1967: The growth modes of ice crystals in supercooled water and aqueous solutions. J. Glaciology 6, 651-662.

Yamashita, A., 1969: Uncommon ice crystals observed in a large cold room. J. Meteor. Soc. Japan, 47, $57-58$.

, 1971: Trigonal Ice crystals grown in free fall. (to be published) 


\title{
降雪実験で得られた外見が六角対称でない雪の骸晶
}

\author{
山下晃
}

東京大学理学部地球物理学教室

高さ $15 \mathrm{~m}$ の大型低温塔を使って，自由落下中に成長する雪の結晶を容易にかつ多量に得ることができる. 本論文 では，一連の実験の中から，ドライアイスあるいは液体窒素で泠やした金属棒で装置内の過冷却雲に種播きする方法 で得られた，外見が六角対称でない雪の結晶を示しその構造と結晶学的意味を論じた。

外見が長方形の板状のもの, 三角柱状のもの，アルファベットの $\mathrm{V}, \mathrm{Y}, \mathrm{X}$ のような形のもの等を偏光顕微鏡を使 って, 数多く細かく観察した結果, これらの中には十分に発達した六角柱状の骹晶の一部分に相当するものが多いこ とがわかった，実際には，多結晶で非常に複難な外見を示すものがかなりあるが，単結晶については上のような解釈 ですべて説明できる，ただし，三角柱状結晶に関しては，やや異なった解釈が必要であり，かつ断熱膨脹を利用した 種播き法で生ずる最も特微的な結晶であるため,ここではあまりふれない，以下にいくつかの重要な結果を列記す る.

$\bigcirc$ 上記の結晶は, $-1.9^{\circ} \mathrm{C} \sim-11.1^{\circ} \mathrm{C}$ および $-20^{\circ} \mathrm{C}$ 以下で多量に観察されたが, $-15^{\circ} \mathrm{C}$ 近くでは生じない.

$\bigcirc-1.9^{\circ} \mathrm{C} \sim-11.1^{\circ} \mathrm{C}$ の領域と, $-20^{\circ} \mathrm{C}$ 以下の領域での結晶習性 (habit) は. 外見上はずい分異なるものが多い が, 大体においては同じと考えてよい.

○これらの結晶は, arm growth (一種の corner growth) と inside 面の板状成長の結果生ずると解される.

○これらの結晶が生ずる事実は, 雪の結晶成長に初期条件（あるいは核の種類）が重要な影響を持つことを示して いる. 